\title{
ENVIRONMENTAL GEOCHEMISTRY AND ASSESSMENT OF POLLUTION BY VANADIUM IN TOP SOIL OF KIRKUK, NORTHERN IRAQ
}

\author{
${ }^{1}$ Haider A. Afloog" and ${ }^{1}$ Hassan A. A. Al-Jumaily \\ ${ }^{1}$ Department of Applied Geology, College of Science, University of Kirkuk, Kirkuk, Iraq \\ "E-mail: haider.abdulhussein1@gmail.com \\ Received: 2July 2020; accepted: 30 September 2020
}

\begin{abstract}
The vanadium geochemistry was estimated in the topsoil of Kirkuk, northern Iraq, and its potential sources are forecasted by using multivariate statistical analysis as useful tools in this field, in addition to assessing soil pollution with vanadium by using individual indices such as enrichment factor, geo-accumulation index $\left(I_{\text {geo }}\right)$ and contamination factor $(C F)$. Eighteen topsoil samples were collected with a depth ranges $0-20 \mathrm{~cm}$, and analyzed by using the inductively coupled plasma-mass spectrometer technique (ICP-MS). The results showed that the concentration of vanadium ranged from $37-51 \mathrm{mg} / \mathrm{kg}$, with an average of $46 \mathrm{mg} / \mathrm{kg}$, relatively it was high concentrations in the agricultural and residential areas compared to the industrial areas. Statistical analysis indicated the contribution of oil combustion and the use of phosphate fertilizers in increasing vanadium concentrations in topsoil. Pollution indices of enrichment factor were in the minimal enrichment category for all samples, geo accumulation index was non-contamination categories for all samples, while Contamination factor was low for all samples.
\end{abstract}

Keywords: Vanadium; Kirkuk; Topsoil; Factor analyses; Pollution assessment

\section{INTRODUCTION}

The soil represents a sink for pollutants and provides a means for transporting them into the atmosphere, hydrosphere and biosphere (Alloway, 2012 and Kabata-Pendias, 2010) and its contamination with heavy metal are the most serious problem due to the inability of these elements to decompose and accumulate in the human body which lead to health risks, as it enters the soil through various human activities such as industrial and household waste, cars exhaust gases, and emissions from factory chimneys (Awadh, 2015; Khan et al., 2015 and AlJaberi et al., 2016). Vanadium is one of these elements which represents an important pollutant in the environment at high levels due to many health risks to which humans are exposed (Schlesinger et al., 2017). Average contents of it in soils range from 10 to $500 \mathrm{mg} / \mathrm{kg}$, and its 
world median content has been established at $90 \mathrm{mg} / \mathrm{kg}$ (Kabata-Pendias and Mukherjee, 2007), and it does not occur as a pure mineral in nature, but it found in about more than 65 different minerals as well as to it's found in carbon-containing deposits such as coal, crude oil, shale rocks and oil sands (Yassin and Al-Awadie, 2014). The combustion of hydrocarbon fuels is the most important anthropogenic source of vanadium, particularly $\mathrm{V}_{2} \mathrm{O}_{5}$ (Mejia et al., 2007). Vanadium has four positive equivalents (II), V(III), V(IV) and V(V), and the two valence V(IV) and $\mathrm{V}(\mathrm{V})$ are most common in the natural environment, $\mathrm{V}(\mathrm{V})$ particularly is more mobile in the surface environment compared with V(IV) which is stable only in acidic conditions and turns gradually to V(V) when the pH increases to greater than 4 (Baken et al., 2012; Pyrzyñska, 2006 and Wisawapipat and Kretzschmar, 2017), in addition to that, V(V) is more toxic and impacted human health (Schiffer and Liber, 2017 and Zou et al., 2019). Vanadium is mainly used as an additive element in steel alloys to increase its hardness and resistance to rust, in electronics and battery industries, also it's using to make fertilizers and some types of medicines (Imtiaz et al., 2015 and Schlesinger et al., 2017). Its many uses have led to an increase in demand for it, which has resulted in doubling its global production in the past fifteen years and thus an increase releases into the environment from industrial processes (Watt et al., 2018).

According to previous studies, Mohammed (2009) showed that the main source of heavy metals in Kirkuk is emissions from burning oil waste, vehicle exhausts and industrial activities. Awadh et al. (2015) used the pollution indices to assessment of soil pollution in al-Hawija (a part of Kirkuk) and concluded it was low contamination with vanadium. Ali (2007) found that based on the geographic accumulation index, the Al-Hawija soil was expressed as not contaminated to a slight contamination with vanadium. The importance of assessing soil contamination with vanadium is that it poses health risks to humans through direct exposure (ingestion, inhalation and dermal contact), or through the food chain (Zou et al., 2019), many studies have reported toxic and carcinogenic effects of vanadium at high concentrations (Wilk et al., 2017). The long-term oral exposure to it may lead to toxic effects to the digestive system include diarrhea, vomiting, low weight, and inflammation of the intestine (Jayawardana et al., 2014 and Wilk et al., 2017). Inhaling particles rich in vanadium can cause many problems because the lung absorbs it well (Barceloux and Barceloux, 1999), that leads to chronic coughing, shortness of breath, bronchitis, lung fibrosis and may lead to lung cancer (IARC, 2006; Jaiswal and Kale, 2019). The objective of this study was to estimate vanadium concentrations and predict its potential sources in the topsoil of Kirkuk, to understand the vanadium geochemistry in it, and assessment the pollution levels of soil with vanadium by using 
individual indices such as enrichment factor $(\mathrm{EF})$, geo-accumulation $\left(\mathrm{I}_{\text {geo }}\right)$, and contamination factor $(\mathrm{CF})$.

\section{STUDY AREA}

The study area represents Kirkuk, northern Iraq, it is $255 \mathrm{~km}$ northeast from the capital,

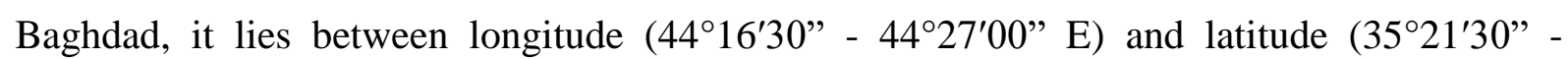
$35^{\circ} 33^{\prime} 00^{\prime} \mathrm{N}$ ). Its area is about $101.14 \mathrm{~km}^{2}$ and its average height about $367 \mathrm{~m}$ above sea level surrounded by the Boor mountain from the north, northeast, and northwest. The seasonal Khassa river runs from north to south and divides it into left and right sides (Fig. 1).

The sediment cover of Kirkuk is made up of clastic rocks include claystone, siltstone, sandstone, and evaporitic rocks include gypsum, and limestone. It is represented by four formations in addition to quaternary deposits, and it is from oldest to newest, the Fatha Formation (Middle Miocene), Injana Formation (Upper Miocene), AL-Mukdadyia Formation (Upper Miocen-Pliocen), Bai Hassan Formation (Pliocen-Pleistocene), and quaternary deposits (Pleistocene-Holocene) (Jassim and Goff, 2006).

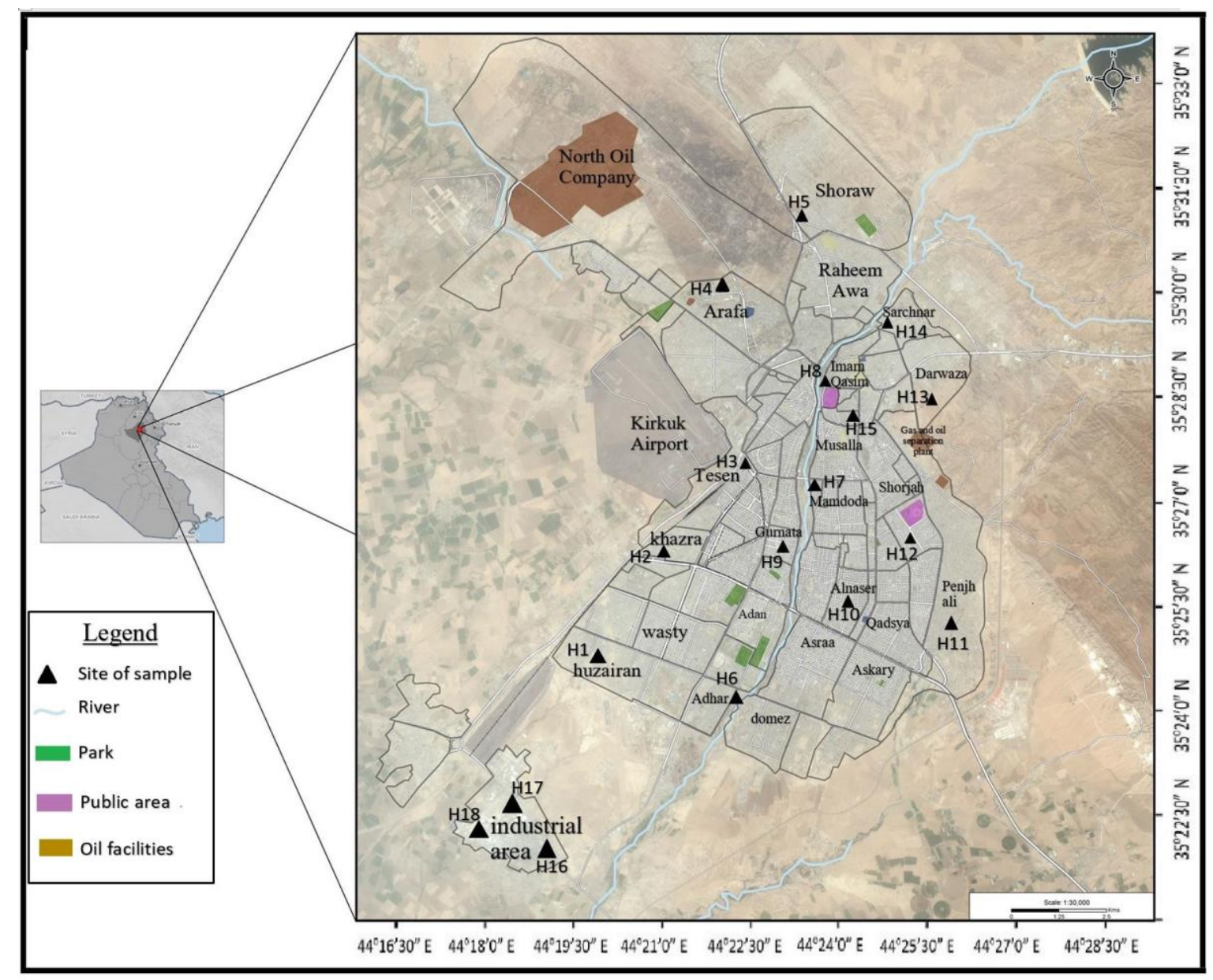

Fig. 1. Map of the study area showing samples sites 


\section{MATERIALS AND METHODS}

\section{Sampling}

Eighteen topsoil samples were collected with a depth of 0-20 cm, distributed over the city's neighborhoods, representing residential, industrial and agricultural areas. Samples were collected by using manual (Auger) method. It was stored in polyethylene bags and transferred to a laboratory.

\section{Laboratory Work}

After the samples are transferred to the laboratory, they are left for a sufficient period of time to dry completely, then agglomerates samples were dismantled by a ceramic mortar, a portion of each sample was sieved with a 200 mesh sieve, and the weight of $20 \mathrm{gm}$ from the passed parts through the sieve was taken and placed in plastic bags. It was then numbered and sent to ACME laboratories in Canada for the purpose of conducting the required chemical analyzes using inductively coupled plasma- mass spectrometer technique (ICP-MS). Perform a volumetric analysis of the samples by taking $40 \mathrm{gm}$ from each sample, then the samples are putted in a cylinder, distilled water is added and mixed well, sand was separated from silt and clay, with wet sieving method using a sieve of 230 mesh. The non-passing portion of the sieve represents the sandy part, while the liquid passing through the sieve represents a mixture of clay and silt, and they were separated by using the pipette analysis method (Carver, 1971 and Folk, 1980).

\section{Statistical Analysis}

Some major, minor, and trace elements such as $\mathrm{Al}_{2} \mathrm{O}_{3}, \mathrm{CaO}, \mathrm{Cr}_{2} \mathrm{O}_{3}, \mathrm{Fe}_{2} \mathrm{O}_{3}, \mathrm{~K}_{2} \mathrm{O}, \mathrm{MgO}, \mathrm{MnO}$, $\mathrm{SiO}_{2}, \mathrm{TiO}_{2}, \mathrm{As}, \mathrm{Cd}, \mathrm{Cl}, \mathrm{Co}, \mathrm{Cu}, \mathrm{Mo}, \mathrm{Ni}, \mathrm{P}, \mathrm{Pb}, \mathrm{Sc}, \mathrm{U}, \mathrm{Zn}$,), and some soil parameters (Organic material and Acidic function), were estimated and statistically processed by correlation coefficient and factor analysis using SPSS v.22 and Xlstat-2019 programs, respectively, to find out their geochemical behavior with vanadium.

\section{Individual Pollution Indices}

For purpose to assess the level of soil contamination by vanadium and to meet the objectives of this study, three individual indices were selected as follows:

\section{Enrichment Factor (EF)}

It is calculated from the following formula (Buat-Menard and Chesselet, 1979):

$$
\mathrm{EF}=\frac{(\mathrm{Ci} / \mathrm{Cr})_{\text {Sampl }}}{(\mathrm{Ci} / \mathrm{Cr})_{\text {Backround }}}
$$


(Ci / Cr) Sample is concentration of the element studied in the sample (Ci) to the concentration of the reference element $(\mathrm{Cr})$ in the sample, $(\mathrm{Ci} / \mathrm{Cr})$ Background is concentration of the studied element to the concentration of the reference element in the natural background sample, and it is divided according to the groups (Table 1).

Table 1. Categories of EF

\begin{tabular}{|l|c|}
\hline EF value & Enrichment category \\
\hline $\mathrm{EF} \leq 2$ & Minimal enrichment \\
\hline $2<\mathrm{EF} \leq 5$ & Moderate enrichment \\
\hline $5<\mathrm{EF} \leq 20$ & Significant enrichment \\
\hline $20<\mathrm{EF} \leq 40$ & Very high enrichment \\
\hline $\mathrm{EF}>40$ & Extremely enrichment \\
\hline
\end{tabular}

\section{Geoaccumulation Index (Igeo)}

The $\mathrm{I}_{\mathrm{geo}}$ is calculated from the following formula, and is divided according to the groups (Table 2) (Yaqin et al., 2008):

$$
\mathrm{I}_{\text {geo }}=\log \frac{\mathrm{C}_{\text {sample }}}{1.5 * \mathrm{C}_{\text {background }}}
$$

$\mathrm{C}_{\text {sample }}$ is concentration of the element in sample, $\mathrm{C}_{\text {background }}$ is geochemical background for same element, 1.5 as a constant introduced to minimize the effect of possible variations in the background values (Hussain and Al-Jaberi, 2020)

Table 2. Categories of geo-accumulation index (Igeo)

\begin{tabular}{|l|c|}
\hline Igeo $_{\text {value }}$ & Category \\
\hline $\mathrm{I}_{\text {geo }} \leq 0$ & Uncontaminated \\
\hline $0<\mathrm{I}_{\text {geo }} \leq 1$ & Uncontaminated to moderately contaminated \\
\hline $1<\mathrm{I}_{\text {geo }} \leq 2$ & Moderately contaminnated \\
\hline $2<\mathrm{I}_{\text {geo }} \leq 3$ & Moderately to heavily contaminated \\
\hline $3<\mathrm{I}_{\text {geo }} \leq 4$ & Heavily contaminated \\
\hline $4<\mathrm{I}_{\text {geo }} \leq 5$ & Heavily to extremely contaminated \\
\hline $5<\mathrm{I}_{\text {geo }}$ & Extremely contaminated \\
\hline
\end{tabular}

\section{Contamination Factor (CF)}

This factor can be calculated with the formula established by Hackanson (1980) as follows:

$$
\mathrm{CF}=\frac{\mathrm{C}_{\text {sample }}}{\mathrm{C}_{\text {backgrund }}}
$$

Where $\mathrm{C}_{\text {sample }}$ represents the concentration of the element studied in the sample, and $\mathrm{C}_{\text {background }}$ is the concentration of the same element in the natural background and is divided according to many categories (Table 3). 
Table 3. Categories of contamination factor (CF)

\begin{tabular}{|l|c|}
\hline $\mathrm{CF}$ value & Category \\
\hline $\mathrm{CF}<1$ & Low $\mathrm{CF}$ \\
\hline $1 \leq \mathrm{CF}<3$ & Moderate $\mathrm{CF}$ \\
\hline $3 \leq \mathrm{CF}<6$ & Considerable CF \\
\hline $\mathrm{CF} \geq$ & Very high $\mathrm{CF}$ \\
\hline
\end{tabular}

\section{RESULTS AND DISCUSSION}

\section{Vanadium Content in the Soil of the Study Area}

According to the results which obtained from the chemical analysis of the samples, it was found that the vanadium concentration ranges between $37-51 \mathrm{mg} / \mathrm{kg}$ and the average is $46 \mathrm{mg} / \mathrm{kg}$, (Table 4), it was found that its highest concentration was $51 \mathrm{mg} / \mathrm{kg}$ for the sites $\mathrm{H} 2$ and $\mathrm{H} 6$, the site $\mathrm{H} 2$ represents Khazraa neighborhood, which is characterized by the presence of places to trade cars, in addition to its location on the highway which is characterized by heavy traffic particularly trucks and tankers that leads to an increase in vanadium concentrations in the soil due to combustion emissions (Teng et al., 2011), as a high percentage of vanadium remains in oil derivatives even after the refining process and release when the fuel burning (Hope, 1997). Whereas the site H6 represents farm on the edge of Khassa river in Adhar neighborhood, and increased vanadium content in this site may be due to the use of phosphate fertilizers which is usually rich in vanadium about $90-180 \mathrm{mg} / \mathrm{kg}$ (Akoumianaki-Ioannidou et al., 2016), and the using vanadium contaminated water for irrigation may increase its concentration in the soil (Naser et al., 2018).

Also, relatively high concentrations appeared at sites $\mathrm{H} 5$ and $\mathrm{H} 7$, as their concentration (50 mg/kg) was both, the H5 site represents Shoraw neighborhood which passes through the highway link Kirkuk and Erbil and is characterized by heavy traffic, which may contribute to increasing the concentration of vanadium, also its location is near the oil company and the Kirkuk refinery and on the northeast side in the same direction as the prevailing wind in the city which contribute of transfer vanadium-rich emissions and deposited in it (Al-Hamdani et al., 2016; AL-Jumaily, 2009 and Awadh and Al-hamdani, 2019). As for the site H7 it represents farm in Mamdoda area and its increase in the concentration of vanadium is due to the use of phosphate fertilizers as mentioned above. It is noted that the average concentration of vanadium, was in the following descending order (Agricultural areas > Residential areas> Industrial areas) (Table 5). 
Table 4. Concentration, range, and average of vanadium in topsoil samples

\begin{tabular}{|c|c|c|c|c|c|}
\hline Symbols of site & Names of site & V (mg/kg) & Symbols of site & Names of site & $\mathrm{V}(\mathrm{mg} / \mathrm{kg})$ \\
\hline $\mathrm{H} 1$ & Huzairan & 49 & H11 & Penja Ali & 44 \\
\hline $\mathrm{H} 2$ & Khazra & 51 & H12 & Shorja & 46 \\
\hline H3 & Tesen & 48 & H13 & Darwaza & 49 \\
\hline $\mathrm{H} 4$ & Arafa & 46 & H14 & Sarchnar & 47 \\
\hline H5 & Shoraw & 50 & H15 & Garaj Alshmal & 37 \\
\hline H6 & Adhar & 51 & H16 & Industrial Area & 40 \\
\hline $\mathrm{H} 7$ & Mamdoda & 50 & H17 & Industrial Area & 43 \\
\hline $\mathrm{H} 8$ & Imam Qasim & 46 & H18 & Industrial Area & 41 \\
\hline H9 & Gurnata & 43 & Range & \multicolumn{2}{|c|}{$(37-51 \mathrm{mg} / \mathrm{kg})$} \\
\hline H10 & Alnaser & 49 & Average & \multicolumn{2}{|c|}{$(46 \mathrm{mg} / \mathrm{kg})$} \\
\hline
\end{tabular}

The relatively high concentration in agricultural areas may be due to the use of fertilizers and pesticides, and may be due to the presence of highly concentrated minerals in industrial areas such as zinc, cadmium, lead and phosphorous, which competes with vanadium for adsorption sites and displaces it based on several factors, including surface charge, soil $\mathrm{pH}$, oxidation state, and soil properties (Nkwopara et al., 2016). Kirkuk soil is derived from formations that cover the city, which generally consist of sedimentary rocks (Jassim and Goff, 2006), and concentration of vanadium in these rocks ranges from $10-20 \mathrm{mg} / \mathrm{kg}$ (KabataPendias and Mukherjee, 2007), its occurrence at higher concentrations may indicate that it is influenced by other sources. Higher levels in agricultural and residential areas compared to industrial areas indicate that the concentrations may have been derived from anthropogenic sources rather than from the geological origin, such as emissions from oil installations and using phosphate fertilizers.

Table 5. Describe the areas from which topsoil samples were collected

\begin{tabular}{|l|c|c|}
\hline Sites description & Sites symbols & Average of V (mg/kg) \\
\hline Agricultural & $\mathrm{H} 6, \mathrm{H} 7, \mathrm{H} 8$ & 49 \\
\hline Residential & $\mathrm{H} 1, \mathrm{H} 2, \mathrm{H} 3, \mathrm{H} 4, \mathrm{H} 5, \mathrm{H} 9, \mathrm{H} 10, \mathrm{H} 11, \mathrm{H} 12, \mathrm{H} 13, \mathrm{H} 14$ & 47.4 \\
\hline Industrial & $\mathrm{H} 15, \mathrm{H} 16, \mathrm{H} 17, \mathrm{H} 18$ & 40.2 \\
\hline
\end{tabular}

\section{Vanadium Distribution in Size Fractions}

Vanadium was analyzed in size fraction (sand, silt and clay) for five soil samples (Table 6), its concentration in sandy fraction ranged between $38-46 \mathrm{mg} / \mathrm{kg}$ with average $40.8 \mathrm{mg} / \mathrm{kg}$ and silty fraction ranges from $43-50 \mathrm{mg} / \mathrm{kg}$ with average of $45.6 \mathrm{mg} / \mathrm{kg}$, in clay fraction ranges from $45-$ $56 \mathrm{mg} / \mathrm{kg}$ with average of $49.6 \mathrm{mg} / \mathrm{kg}$, and his concentration in size fraction was in order of Sand < Silt < Clay (Fig. 2), consistent with what mentioned by Sun et al. (2019) that the sandy soil is less retaining vanadium than clay soil. And also consistent with Kaplan et al. (1990), the vanadium is more related to fine soil than coarse soil. Sometimes its concentration in the fine 
grains may exceed those found in the parent rocks (Kabata-Pendias and Pendias, 1985). In general, it is usually associated with the clay fraction and clay minerals of the soil and its abundance increases with increase of these minerals in the soil (Breit and Wanty, 1991 and Ivanov and Kashin, 2010), and ion exchange and/or adsorption on these minerals represent the major mechanism of its accumulation in the soil (Ghani et al., 2012).

Table 6. Concentrations of vanadium in the size fractions soil in units (mg/kg)

\begin{tabular}{|l|c|c|c|}
\hline Sample number & V (sand) & V (silt) & V (clay) \\
\hline H4 & 42 & 47 & 50 \\
\hline H6 & 46 & 50 & 56 \\
\hline H15 & 40 & 43 & 46 \\
\hline H16 & 38 & 44 & 45 \\
\hline H17 & 38 & 44 & 50 \\
\hline Average & 40.8 & 45.6 & 49.6 \\
\hline
\end{tabular}

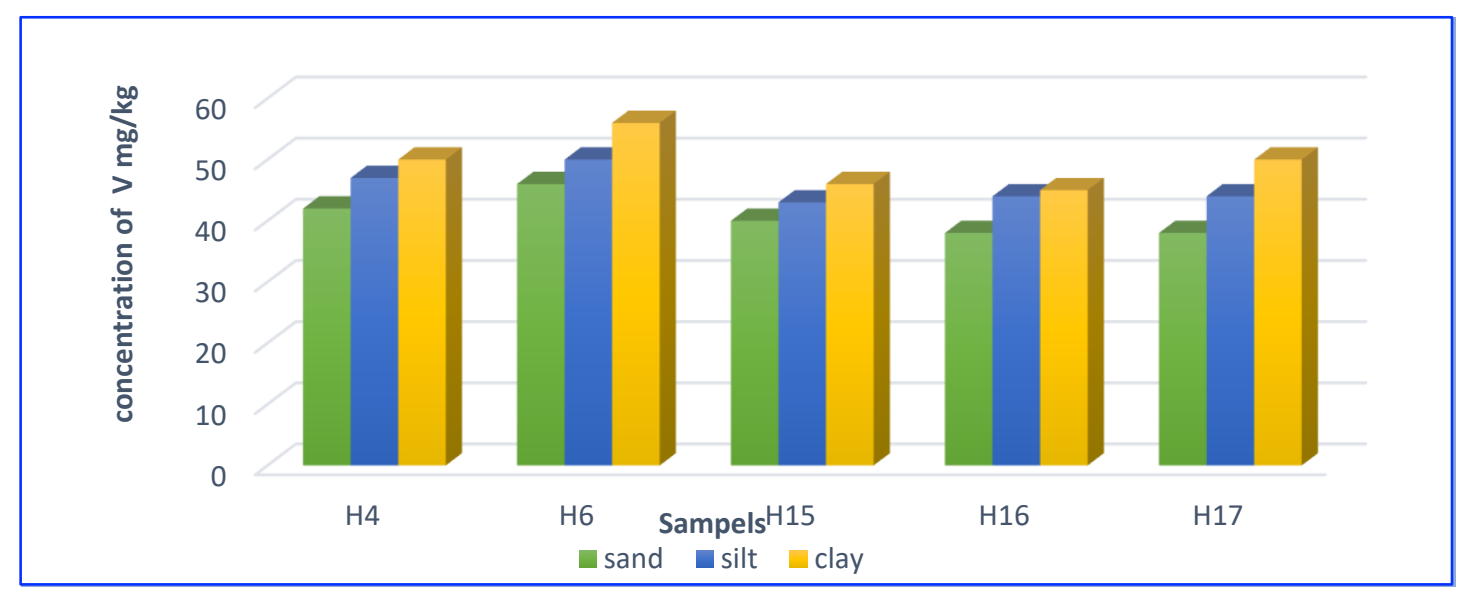

Fig. 2. Vanadium concentration in size fraction of soil

\section{Effect of pH on the Valence State of Vanadium in Soil}

Soil colloids, such as metal oxides, organic matter and clay minerals, are characterized by the presence of two types of charge, a permanent charge that is not affected by the $\mathrm{pH}$, and a variable charge that depends on the $\mathrm{pH}$, when the $\mathrm{pH}$ is greater than 7 , soil has a negative net charge, and at lower values $(\mathrm{pH}<7)$ its net charge is positive (Karak et al., 2005 and Sherene, 2010). Thus, the soil $\mathrm{pH}$ is a major factor controlling the heavy metal content in the soil, and these elements may accumulate and bind to it, with the possibility of activating and transferring them later when the $\mathrm{pH}$ values change and Othman et al., 2020). At a low pH the solubility and transportability of most cation heavy metals increases and their adsorption decreases due to electrostatic repulsion, and competition for adsorption sites with anions such as $\mathrm{CO}_{3}, \mathrm{SO}_{4}, \mathrm{PO}_{4}$, and $\mathrm{Cl}$ (Peng et al., 2009). Its ability to accumulate increases with increasing $\mathrm{pH}$ when the 
adsorbed surfaces carry negative charges, but vanadium has different geochemical behavior (Aihemaiti et al., 2019), because of its ability to form cation and anion, depending on soil $\mathrm{pH}$, tetravalence $\mathrm{V}(\mathrm{IV})$ cation type prevails at $\mathrm{pH}<4$ and in reduction conditions, gradually turns to pentavalent $\mathrm{V}(\mathrm{V})$ in anion form when increasing $\mathrm{pH}$ values and or increasing oxygen, whereas the pentavalent prevails at $\mathrm{pH}$ values $(\mathrm{pH}>8)$ in both the reducing and oxidizing conditions (Hu et al., 2018; Jiang et al., 2019; Wisawapipat and Kretzschmar, 2017 and Zhu et al., 2018). In the current study, the values of $\mathrm{pH}$ in the Kirkuk soil ranged from 8-8.6 with an average of 8.2 (Table 7), which means that the soil of the city is alkaline and indicates the presence of pentavalent vanadium $\mathrm{V}(\mathrm{V})$ in its soil, which has the most health risks compared to V(IV), due to its solubility, mobility and bioavailability (Reijonen et al., 2016 and Shaheen et al., 2014), this can be attributed to the competition between the hydroxyl ion $\left(\mathrm{OH}^{-}\right)$with vanadium anions on the available surface sites in the soil (Naeem et al., 2007), or to the electrostatic repulsion between the negative charges of both vanadium and the adsorbent material (Wällstedt et al., 2010).

Table 7. pH values of soil samples

\begin{tabular}{|c|c|c|c|}
\hline Site & $\mathbf{p H}$ & Site & $\mathbf{p H}$ \\
\hline H1 & 8.6 & H11 & 8.1 \\
\hline H2 & 8.4 & H12 & 8.1 \\
\hline H3 & 8.2 & H13 & 8.2 \\
\hline H4 & 8.2 & H14 & 8.1 \\
\hline H5 & 8.1 & H15 & 8.2 \\
\hline H6 & 8.4 & H16 & 8.2 \\
\hline H7 & 8.5 & H17 & 8.4 \\
\hline H8 & 8 & H18 & 8.1 \\
\hline H9 & 8.3 & Range & $8-8.6$ \\
\hline H10 & 8.3 & Average & 8.2 \\
\hline
\end{tabular}

\section{Statistical Analysis}

For the purpose of performing statistical analysis, the concentrations of some major, minor and trace elements as well as organic matter were estimated (Table 8).

\section{Correlation coefficient}

Correlation coefficient is an effective way to detect relationships between different elements, when there is strong positive correlation between two elements indicate that they may have the same source, and strong negative correlation indicate different sources (Micó et al., 2006). The 
correlation coefficient of vanadium was calculated with some major, minor, trace elements, and some soil properties, (Table 9).

Table 8. Concentrations major, minor, trace elements and organic matters

\begin{tabular}{|c|c|c|c|c|c|c|c|}
\hline Element & Min. & Max. & Average & Element & Min. & Max. & Average \\
\hline $\mathrm{Mo} \mathrm{mg} / \mathrm{kg}$ & 0.39 & 4.88 & 1.423 & $\mathrm{MgO} \%$ & 2.51 & 4.788 & 3.661 \\
\hline $\mathrm{Cu} \mathrm{mg} / \mathrm{kg}$ & 19.46 & 197.13 & 61.423 & $\mathrm{Al}_{2} \mathrm{O}_{3} \%$ & 5.497 & 9.146 & 7.490 \\
\hline $\mathrm{Pb} \mathrm{mg} / \mathrm{kg}$ & 9.4 & 527.15 & 85.682 & $\mathrm{SiO}_{2} \%$ & 27.02 & 41.42 & 35.736 \\
\hline $\mathrm{Zn} \mathrm{mg/kg}$ & 48.8 & 740.3 & 189.306 & $\mathrm{Cl} \%$ & 0.00014 & 0.0785 & 0.028 \\
\hline $\mathrm{Ni} \mathrm{mg} / \mathrm{kg}$ & 77.4 & 143.7 & 104.311 & $\mathrm{~K}_{2} \mathrm{O} \%$ & 0.9917 & 1.808 & 1.321 \\
\hline $\mathrm{Co} \mathrm{mg} / \mathrm{kg}$ & 12.5 & 18 & 14.800 & $\mathrm{CaO}_{4}$ & 20.59 & 33.21 & 24.733 \\
\hline $\mathrm{As} \mathrm{mg} / \mathrm{kg}$ & 4.7 & 6.9 & 5.872 & $\mathrm{TiO}_{2} \%$ & 0.06254 & 0.6461 & 0.542 \\
\hline $\mathrm{U} \mathrm{mg} / \mathrm{kg}$ & 0.5 & 0.8 & 0.611 & $\mathrm{Cr}_{2} \mathrm{O}_{3} \%$ & 0.0393 & 0.1153 & 0.056 \\
\hline $\mathrm{Cd} \mathrm{mg} / \mathrm{kg}$ & 0.17 & 1.04 & 0.417 & $\mathrm{MnO}_{2} \%$ & 0.0768 & 0.1784 & 0.100 \\
\hline $\mathrm{Sc} \mathrm{mg} / \mathrm{kg}$ & 3.5 & 6.2 & 4.717 & $\mathrm{Fe}_{2} \mathrm{O}_{3} \%$ & 3.875 & 9.29 & 5.184 \\
\hline $\mathrm{P} \%$ & 0.046 & 0.136 & 0.078 & $\mathrm{O}_{2} \%$ M. & 0.573 & 6.261 & 2.443 \\
\hline
\end{tabular}

Table 9. The correlation coefficient of vanadium with the chemical components

\begin{tabular}{|c|c|c|c|c|c|}
\hline Element & $\mathrm{V}$ & Element & $\mathrm{V}$ & Element & $\mathrm{V}$ \\
\hline $\mathrm{V}$ & 1 & $\mathrm{Cd}$ & $-0.814^{* *}$ & $\mathrm{Cl}$ & $-0.664^{* *}$ \\
\hline $\mathrm{Mo}$ & $-0.777^{* *}$ & $\mathrm{SC}$ & $0.694 * *$ & $\mathrm{~K}_{2} \mathrm{O}$ & $0.695^{* *}$ \\
\hline $\mathrm{Cu}$ & $-0.732^{* *}$ & $\mathrm{U}$ & 0.057 & $\mathrm{Fe}_{2} \mathrm{O}_{3}$ & -0.363 \\
\hline $\mathrm{Pb}$ & $-0.775^{* *}$ & $\mathrm{P}$ & $-0.676^{* *}$ & $\mathrm{TiO}_{2}$ & $0.618^{* *}$ \\
\hline $\mathrm{Zn}$ & $-0.836^{* *}$ & $\mathrm{CaO}$ & -0.343 & $\mathrm{Cr}_{2} \mathrm{O}_{3}$ & 0.292 \\
\hline $\mathrm{Ni}$ & $0.771^{* *}$ & $\mathrm{MgO}$ & $0.911^{* *}$ & $\mathrm{MnO}$ & -0.257 \\
\hline $\mathrm{Co}$ & $0.688^{* *}$ & $\mathrm{Al}_{2} \mathrm{O}_{3}$ & $0.902 * *$ & $\mathrm{O}$ & $-0.855^{* *}$ \\
\hline $\mathrm{As}$ & 0.379 & $\mathrm{SiO}_{2}$ & $0.801 * *$ & $\mathrm{MH}$ & $0.489 *$ \\
\hline
\end{tabular}

**. Correlation is significant at the 0.01 level

*. Correlation is significant at the 0.05 level

Vanadium showed a positive correlation with $\mathrm{Al}_{2} \mathrm{O}_{3}$, it may be due to accompanying in bauxite mineral (Ruyters et al., 2011), and attributed to direct adsorption on clay minerals (Ivanov and Kashin, 2010), or indirect by the negative charge reflection mechanism of the clay minerals surfaces, so $\mathrm{Al}^{+3}$ ions can adsorb to the surfaces of clay minerals, and change their charge to positive and lead to the adsorption of vanadium, potassium ions also act by the same mechanism and this is observed through the positive correlation with $\mathrm{K}_{2} \mathrm{O}$ (Huang and Yang, 2020). Vanadium showed a positive correlation with $\mathrm{MgO}$ with a value of $\mathrm{r}=0.91$ which may be due to their geochemistry accompanying in clay minerals and silicate minerals, or for the similarity of their sources as a result of weathering dolomite rocks containing about 30-120 mg/kg of magnesium (Gransee and Führs, 2013; Mayland and Wilkinson, 1989). It also has a 
positive relationship with $\mathrm{SiO}_{2}$ by value $\mathrm{r}=0.8$, which may be due to vanadium adsorption on silica, which is high in alkaline soils (Gan et al., 2020) and has a positive correlation with $\mathrm{TiO}_{2}$ with a value $r=0.61$ which is due to the enrichment of titanium minerals with vanadium and can be attributed to its adsorption on $\mathrm{TiO}_{2}$ (Gäbler et al., 2009). It is associated in a positive correlation with Sc a value of $(r=0.69)$, as they are found together in many minerals, including llmenite, rutile, gauthite, hematite, aluminum and titanium minerals (Zhang et al., 2017).

Vanadium has a positive correlation with Ni may due to their presence in petroleum and petroleum products (Rzger et al., 2018) and it is positively correlated with Co which may be attributed to the similarities of their characteristics lithophilic in the earth's crust and sederophilic at the core of the earth (Pourret and Faucon, 2018), in addition to their presence in fossil fuels and phosphate fertilizers (Linhares et al., 2019). The similarity of the chemical structure of vanadium and phosphorous leads to the significant effect of phosphorous presence on vanadium interactions in the soil (Mandiwana and Panichev, 2004), this is obvious by the negative correlation between them, its value $r=-0.67$, which is due to the mechanism of competition between them unlike most elements that show a tendency to bind to phosphorous (Nalewajko et al., 1995), and the presence of phosphates may cause reduced vanadium adsorption on minerals in soil, or may lead to desorption of vanadium (Yang et al., 2014) also phosphorous can be replaced with vanadium in many minerals (Liu et al., 2018).

Vanadium has a negative correlation (r) with $\mathrm{Pb}, \mathrm{Cu}, \mathrm{Zn}$, and $\mathrm{Cd}$ with values of -0.77 , $0.73,-0.83$ and -0.81 , respectively, which may be due to their different sources, or this may be due to the fact that the soil in the study area is alkaline and has a negative charge so therefore the reactions of absorption and ion exchange with these cationic elements are greater than vanadium anions (Bolan et al., 1999). It was also negatively correlation with organic matter (r $=-0.855)$, which may be attributed to the fact that the tetravalence vanadium, which is a cationic form and is tends to bind to the organic matter while pentavalent of it as in the study area are associated with soil oxides and minerals such as aluminum and titanium (Gustafsson, 2019; AlJaberi and Al-Jafar 2020), increasing organic matter in soil may increase its transport and bioavailability because the adsorption of the organic matter to the anions is much less than its adsorption to cations (Reijonen et al., 2016).

\section{Factor analysis}

Is one of the simplest and most widely used statistical methods in multivariate statistical analysis. It helps in understanding and interpreting the relationships between these variables by reducing the large number of variables to a smaller number. The first factor represents the best compatibility of the first basic components and the second factor represents the best 
compatibility of the second basic components that were not calculated in the first factor, thus the third and fourth factor. The first factor usually explains the highest percentage of variance (Muhammad and Ali, 2018). In the present study, four factors were relied upon after Varimax rotation, these factors explain $79.24 \%$ of the total variance, (Table 10). The communality value of vanadium is 0.920 and represents most of its variance, (Table 11).

Table 10. Eigenvalue, variability for each factor and cumulative ratios after rotation

\begin{tabular}{|c|c|c|c|c|}
\hline & F1 & F2 & F3 & F4 \\
\hline Eigenvalue & 9.462 & 9.271 & 2.150 & 2.106 \\
\hline Variability (\%) & 32.604 & 31.960 & 7.416 & 7.265 \\
\hline Cumulative \% & 32.604 & 64.564 & 71.980 & 79.245 \\
\hline
\end{tabular}

Table 11. Factor loading and communality after rotation

\begin{tabular}{|c|c|c|c|c|c|}
\hline Element & $\mathbf{F 1}$ & $\mathbf{F 2}$ & $\mathbf{F 3}$ & $\mathbf{F 4}$ & Communality \\
\hline $\mathrm{V}$ & $\mathbf{0 . 7 3 3}$ & $\mathbf{- 0 . 5 5 4}$ & 0.186 & -0.204 & 0.920 \\
\hline $\mathrm{Mo}$ & $\mathbf{- 0 . 4 2 5}$ & $\mathbf{0 . 8 5 6}$ & 0.154 & 0.124 & 0.952 \\
\hline $\mathrm{Cu}$ & -0.314 & $\mathbf{0 . 9 3 3}$ & 0.025 & 0.041 & 0.971 \\
\hline $\mathrm{Pb}$ & $\mathbf{- 0 . 5 1 5}$ & $\mathbf{0 . 6 4 6}$ & 0.239 & 0.224 & 0.790 \\
\hline $\mathrm{Zn}$ & $\mathbf{- 0 . 4 9 3}$ & $\mathbf{0 . 7 6 0}$ & -0.130 & 0.172 & 0.867 \\
\hline $\mathrm{Ni}$ & $\mathbf{0 . 8 3 1}$ & -0.270 & 0.267 & -0.134 & 0.853 \\
\hline $\mathrm{Co}$ & $\mathbf{0 . 8 2 6}$ & -0.120 & 0.291 & -0.170 & 0.809 \\
\hline $\mathrm{As}$ & $\mathbf{0 . 6 0 2}$ & 0.106 & 0.092 & $\mathbf{0 . 4 5 2}$ & 0.586 \\
\hline $\mathrm{U}$ & 0.070 & -0.157 & $\mathbf{- 0 . 5 4 1}$ & 0.190 & 0.358 \\
\hline $\mathrm{Cd}$ & $\mathbf{- 0 . 4 0 5}$ & $\mathbf{0 . 8 7 4}$ & -0.127 & 0.128 & 0.961 \\
\hline $\mathrm{P}$ & -0.152 & $\mathbf{0 . 8 4 8}$ & -0.390 & 0.051 & 0.897 \\
\hline $\mathrm{Sc}$ & $\mathbf{0 . 7 9 6}$ & -0.314 & 0.200 & 0.236 & 0.827 \\
\hline $\mathrm{MgO}_{\mathrm{Al}} \mathrm{Al}_{3}$ & $\mathbf{0 . 7 5 9}$ & $\mathbf{- 0 . 5 3 4}$ & 0.159 & -0.091 & 0.894 \\
\hline $\mathrm{SiO}_{2}$ & $\mathbf{0 . 9 3 7}$ & $\mathbf{- 0 . 5 0 1}$ & 0.087 & 0.041 & 0.959 \\
\hline $\mathrm{Cl}$ & -0.278 & -0.149 & 0.056 & -0.202 & 0.884 \\
\hline $\mathrm{K}_{2} \mathrm{O}$ & $\mathbf{0 . 8 2 9}$ & -0.358 & -0.115 & 0.236 & 0.834 \\
\hline $\mathrm{CaO}$ & $\mathbf{- 0 . 7 7 4}$ & -0.225 & 0.177 & -0.041 & 0.883 \\
\hline $\mathrm{TiO}_{2}$ & $\mathbf{0 . 8 1 4}$ & 0.137 & 0.086 & -0.454 & 0.682 \\
\hline $\mathrm{Cr}_{2} \mathrm{O}_{3}$ & 0.182 & -0.037 & 0.108 & $\mathbf{- 0 . 8 4 8}$ & 0.896 \\
\hline $\mathrm{MnO}$ & 0.139 & $\mathbf{0 . 8 8 9}$ & 0.139 & -0.275 & 0.904 \\
\hline $\mathrm{Fe}_{2} \mathrm{O}_{3}$ & 0.076 & $\mathbf{0 . 9 2 4}$ & 0.050 & -0.149 & 0.883 \\
\hline $\mathrm{LOI}$ & -0.306 & -0.163 & -0.240 & -0.267 & 0.249 \\
\hline $\mathrm{O}_{\mathrm{M}}$ & $\mathbf{- 0 . 4 8 8}$ & $\mathbf{0 . 6 9 7}$ & -0.318 & 0.235 & 0.881 \\
\hline $\mathrm{pH}$ & 0.201 & -0.046 & $\mathbf{0 . 5 5 9}$ & 0.204 & 0.397 \\
\hline & & & & & \\
\hline
\end{tabular}


First factor (F1)

This factor explains $32.604 \%$ of the total variance, (Table 10), and vanadium appeared with a significant positive load value of 0.733 on this factor (Table 11), in addition to positive loading of $\mathrm{Al}_{2} \mathrm{O}_{3}, \mathrm{MgO}, \mathrm{K}_{2} \mathrm{O}, \mathrm{SiO}_{2}, \mathrm{TiO} 2, \mathrm{Co}, \mathrm{Ni}, \mathrm{Sc}$, and As, Whereas, the significant negative loads were for $\mathrm{Pb}, \mathrm{Zn}, \mathrm{Cd}, \mathrm{Mo}, \mathrm{CaO}$, and organic matter, The presence of a group of elements with a positive load and a group with negative load may indicate a different source for each group, When observing Table 12 for factor Score was found an important positive effect of H13 site in F1, (Fig. 3), this site is characterized by its proximity to the Jabal Boor station for crude oil production, it may be a source of vanadium emission, particularly $\mathrm{Ni}$ and Co were a positive load in this factor as the oil contains high concentrations of them (Awadh and Al-Ankaz, 2016). This is also noticeable from positive factor but to a lesser degree for the H4 and H5 sites, which represent the Arafa and Shoraw regions, respectively, possibly due to their proximity to north oil company. As for the sites H6, H7 and H8, they represent agricultural areas and they had a positive effect in the first factor score, which indicates the agricultural source of vanadium as chemical fertilizers and pesticides (Alloway, 1995). From the Biplot diagram (Fig. 4), it was found that the positive loading of vanadium and the rest elements were associated with positive effects of agricultural and residential sites on this factor and that the negative loads of the elements were associated with the industrial sites, indicating that they did not contribute to this factor.

Table 12. Factor scores after rotation

\begin{tabular}{|c|c|c|c|c|}
\hline Sites & F1 & F2 & F3 & F4 \\
\hline H1 & -0.415 & -0.944 & 0.208 & -0.184 \\
\hline H2 & 0.385 & -0.730 & 0.677 & 0.601 \\
\hline H3 & 0.196 & -0.219 & 0.663 & -0.678 \\
\hline H4 & 0.469 & -0.056 & -1.801 & 1.013 \\
\hline H5 & 0.345 & -0.434 & 0.244 & -2.987 \\
\hline H6 & 1.228 & -0.133 & 0.884 & -0.015 \\
\hline H7 & 1.416 & -0.104 & 1.162 & 0.704 \\
\hline H8 & 0.792 & -0.056 & -1.441 & -0.362 \\
\hline H9 & -1.152 & -0.807 & 0.676 & 0.040 \\
\hline H10 & 0.589 & -0.300 & 0.652 & 0.538 \\
\hline H11 & -0.692 & -0.419 & -2.141 & -0.659 \\
\hline H12 & -1.695 & -1.507 & 0.263 & -0.713 \\
\hline H13 & 1.523 & -0.283 & 0.065 & 0.860 \\
\hline H14 & 0.285 & -0.456 & -0.930 & 1.012 \\
\hline H15 & -2.256 & 0.400 & 1.092 & 1.606 \\
\hline H16 & -0.763 & 1.479 & -1.128 & 0.390 \\
\hline H17 & 0.003 & 2.422 & 0.822 & -0.866 \\
\hline H18 & -0.256 & 2.148 & 0.035 & -0.302 \\
\hline
\end{tabular}




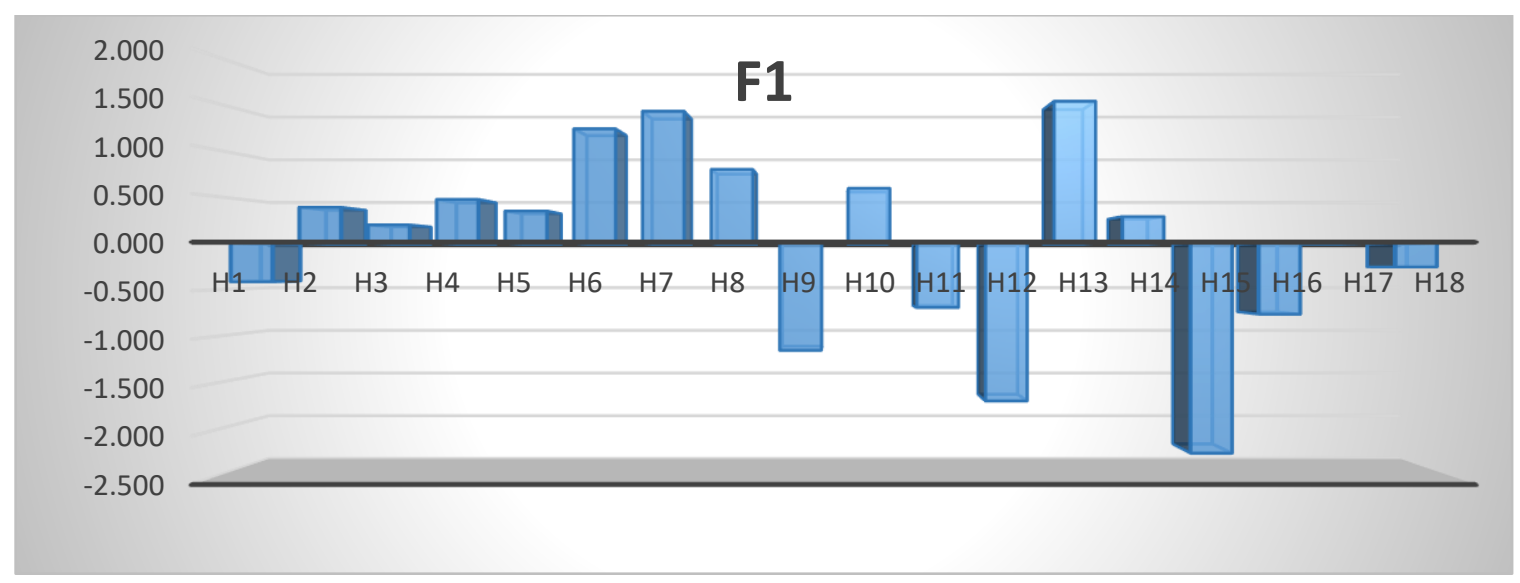

Fig. 3. Factor score for $F 1$ after rotation

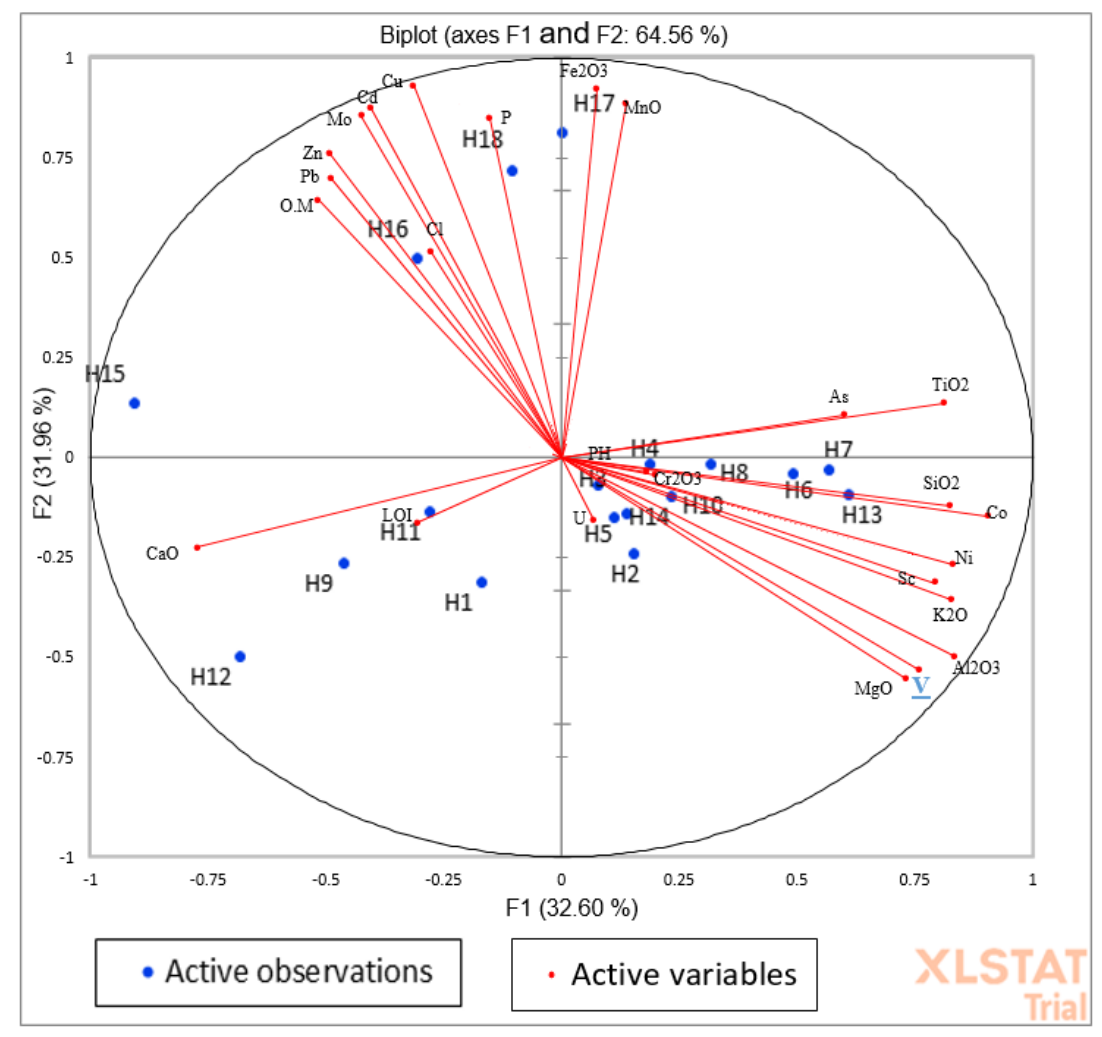

Fig. 4. Biplot diagram after rotation

Second factor (F2)

This factor explains 31.96 of the total variance (Table 10), it appeared that vanadium had a negative load of 0.554 on this factor, (Table 11), and positive loading of the elements appeared ( $\mathrm{Mo}, \mathrm{Cu}, \mathrm{Pb}, \mathrm{Zn}, \mathrm{Cd}, \mathrm{P}, \mathrm{Cl}, \mathrm{MnO}$ and $\mathrm{Fe}_{2} \mathrm{O}_{3}$ ) which is often enriched by industrial activity, like a car repairing garage, blacksmithing, plumbing cars, and others, this indicates the influence of industrial sources on this factor. The factor scores for F2, (Table 12), and (Fig. 5) showed negative loads for all sites except H15, H16, H17 and H18, which represent the industrial sites, indicates that it was not an important source of vanadium in the study area. 


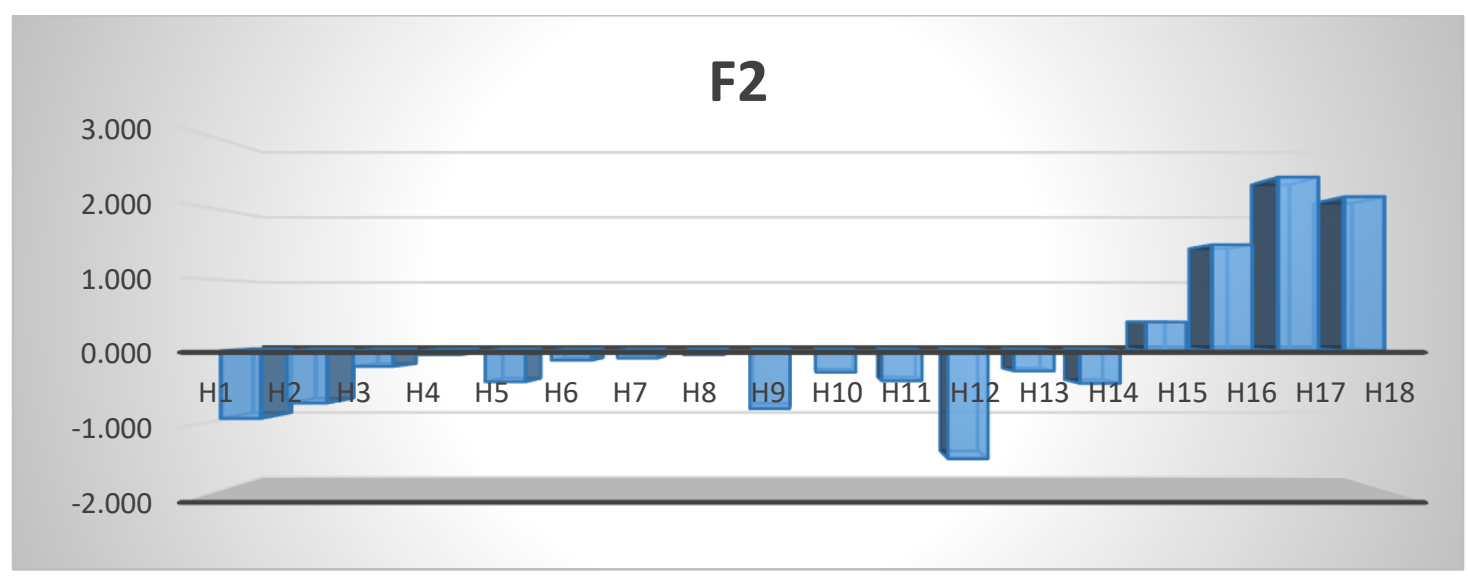

Fig. 5. Factor score for $F 2$ after rotation

Third factor (F3)

This factor explains (7.416\%) of the total variance (Table 10), and vanadium showed a relatively low positive load (0.186), and an important positive loading of the acidic function, as there were positive loading of the $\mathrm{Co}, \mathrm{Ni}, \mathrm{Pb}$ and $\mathrm{Mo}$ in a few proportions too, while there appeared negative loading of chlorine and uranium, (Table 11). Therefore, these convergent and dispersed distributions often indicate that this factor is not affected industrial and agricultural sources significantly and is likely to be from natural sources, (Table 12) and ((Fig. 6).

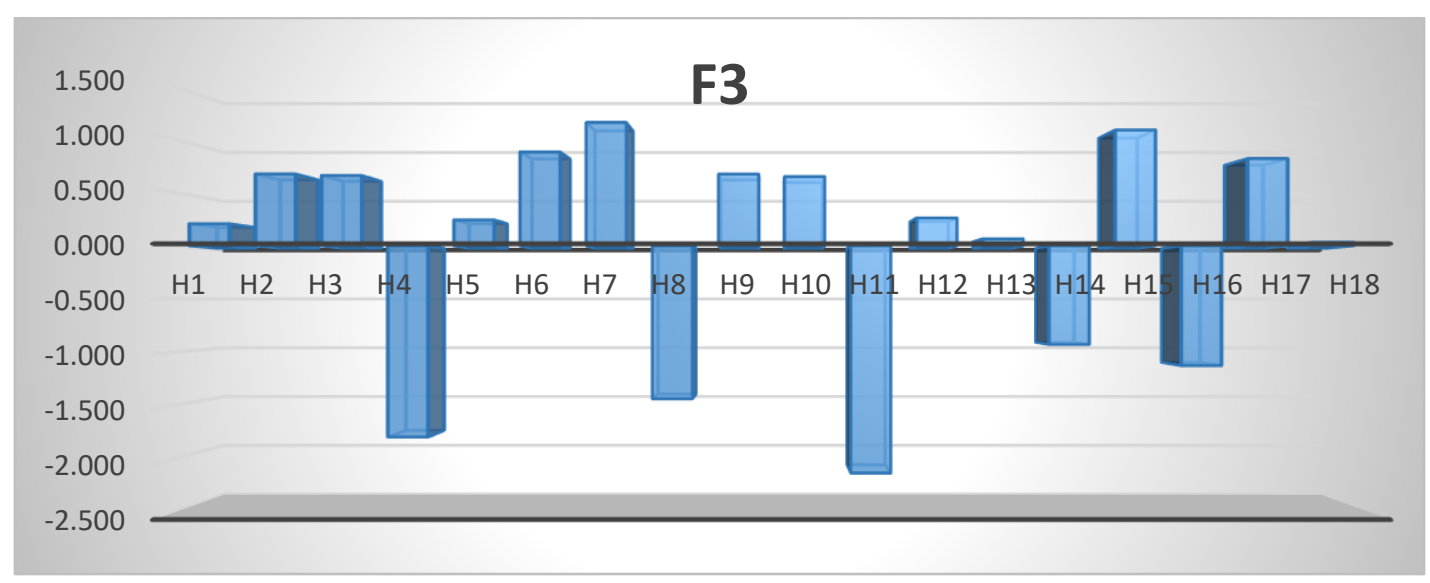

Fig. 6. Factor score for $F 3$ after rotation

Fourth factor (F4)

This factor explains $7.416 \%$ of the total variance, (Table 10), and vanadium showed negative load (-0.204) (Table 11), which means that this factor is not explain potential sources of vanadium, and an important positive loading of arsenic only. From the observation of Table 12 and Fig. 7, it was found a relatively higher contribution of site H15 which may indicate the industrial source of arsenic in the study area, contributions to sites H14, H4, and $\mathrm{H} 7$ (residential sites) have also been observed which may indicate the contribution of natural sources also to this factor. 


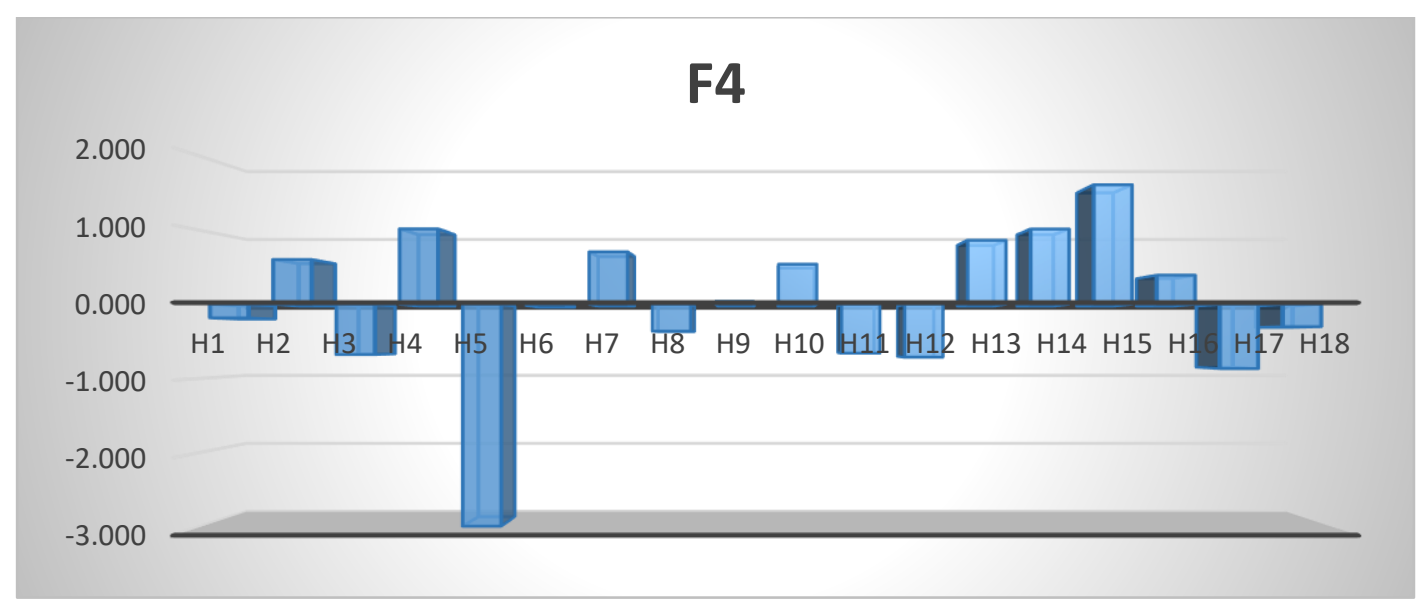

Fig. 7. Factor score for $\mathbf{F} 4$ after rotation

\section{Pollution Assessment}

\section{Enrichment factor (EF)}

It is widely used to determine enrichment of an element in a sample due to human activities than natural abundance, and assess the presence and depth of anthropogenic pollutants in the soil, requires careful selection of the background value of the element under study and the reference component (Ahmad et al., 2019 and Bern et al., 2019). The reference element is usually of low contrast in nature, such as $\mathrm{Al}, \mathrm{Fe}, \mathrm{Mn}$, Ti and Sc. Iron is often used because it is Abundance in the earth's crust and has homogeneous distribution in it (Alekseenko and Alekseenko, 2014; Pragg and Mohammed, 2018). The EF enrichment factor for vanadium was calculated in soil samples for the study area (Table 13) and (Fig. 8), the results showed all samples were in the Minimal Enrichment Category $(\mathrm{EF} \leq 2)$.

\section{Geo-accumulation index (Igeo}

This index is used to assess urban pollution by comparing current and pre-industrial concentrations, choosing the background has a huge impact, and a local background if available it will be more suitable (Johansson et al., 2009). The results obtained by calculating the geoaccumulation index, were less than zero for all samples Igeo $\leq 0$ (Table 13) and (Fig. 8), and it was within the Uncontaminated Category.

\section{Contamination factor $(\mathrm{CF})$}

This factor provides an assessment of soil pollution and is calculated from the ratios of the heavy metal content in the sample to its ratio in the pre-industrial reference level (Hakanson, 1980). In this study the (CF) value was less than 1 for all samples (Table 13) and (Fig. 8), which mean it's of low contamination category. 


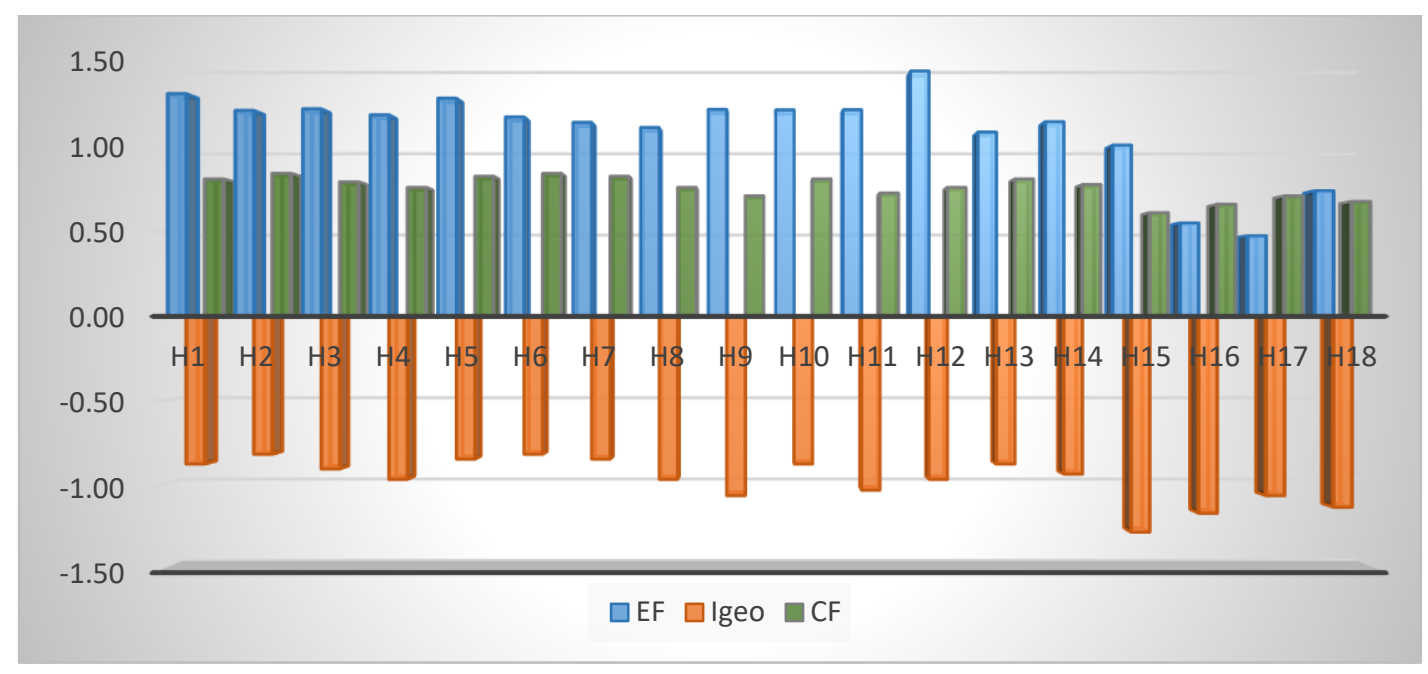

Fig. 8. EF, Igeo, and CF values

Table 13. V, Fe concentrations, and values of EF, $\mathbf{I}_{\text {geo, }}$ and $\mathrm{CF}$ for sites

\begin{tabular}{|l|c|c|c|c|c|}
\hline Sample No. & $\mathbf{V}(\mathbf{m g} / \mathbf{k g})$ & $\mathbf{F e}(\mathbf{m g} / \mathbf{k g})$ & $\mathbf{E F}$ & $\mathbf{I g e o}$ & $\mathbf{C F}$ \\
\hline H1 & 49 & 2160 & 1.32 & -0.88 & 0.82 \\
\hline H2 & 51 & 2430 & 1.22 & -0.82 & 0.85 \\
\hline H3 & 48 & 2270 & 1.23 & -0.91 & 0.80 \\
\hline H4 & 46 & 2240 & 1.20 & -0.97 & 0.77 \\
\hline H5 & 50 & 2250 & 1.30 & -0.85 & 0.83 \\
\hline H6 & 51 & 2510 & 1.19 & -0.82 & 0.85 \\
\hline H7 & 50 & 2530 & 1.15 & -0.85 & 0.83 \\
\hline H8 & 46 & 2390 & 1.12 & -0.97 & 0.77 \\
\hline H9 & 43 & 2040 & 1.23 & -1.07 & 0.72 \\
\hline H10 & 49 & 2330 & 1.23 & -0.88 & 0.82 \\
\hline H11 & 44 & 2090 & 1.23 & -1.03 & 0.73 \\
\hline H12 & 46 & 1840 & 1.46 & -0.97 & 0.77 \\
\hline H13 & 49 & 2610 & 1.10 & -0.88 & 0.82 \\
\hline H14 & 47 & 2370 & 1.16 & -0.94 & 0.78 \\
\hline H15 & 37 & 2120 & 1.02 & -1.28 & 0.62 \\
\hline H16 & 40 & 4200 & 0.56 & -1.17 & 0.67 \\
\hline H17 & 43 & 5230 & 0.48 & -1.07 & 0.72 \\
\hline H18 & 41 & 3200 & 0.75 & -1.13 & 0.68 \\
\hline Average & 46 & 2600 & 1.11 & -0.97 & 0.77 \\
\hline Background* & 60 & 3500 & \multicolumn{3}{|l}{} \\
\hline *(Kabata-Pendias and Mukherjee, 2007$)$ & & & \\
& & & & \\
\hline
\end{tabular}

\section{CONCLUSIONS}

1. The current study showed that the concentration of vanadium was in the following order: Agricultural > Residential > Industrial areas, and its increase in agricultural areas is due to the use of chemical fertilizers, as for its increase in residential areas, it can be attributed to its proximity to places of burning oil and its derivatives and car emissions, 
which indicates that they are sources that contribute to enriching the surface soil with this element.

2. The highest concentration of vanadium was in the clay fractions compared to the silty and sandy fractions, due to its adsorption on the surfaces of clay minerals and the strength of the ion exchange and as an alkaline nature of Kirkuk soil likely that vanadium in its soil is an anionic form that is the most soluble and bioavailability.

3. Vanadium showed many correlations, including a positive correlation with $\mathrm{Al}_{2} \mathrm{O}_{3}, \mathrm{MgO}$, $\mathrm{K}_{2} \mathrm{O}$, and $\mathrm{SiO}_{2}$, which were attributed to adsorption on clay minerals. It also had a positive correlation with $\mathrm{Ni}$ and $\mathrm{Co}$, which is due to the similarity of its sources from the combustion of oil and its derivatives and has an important negative correlation with phosphates, which is due to the similarity among them in the chemical structure, which enhances competition between them on the adsorption sites available in the soil.

4. The results of the factor analysis support that the emissions of burning crude oil and its derivatives and phosphate fertilizers contributed to increasing the concentration of vanadium in the soil of the study area. But despite the contribution of anthropogenic sources to increasing vanadium, individual pollution indices EF, Igeo and CF showed that the contamination of vanadium topsoil in Kirkuk was among the non-contamination categories and that the enrichment from anthropogenic sources was relatively low and not disturbing the environment

\section{ACKNOWLEDGMENTS}

The authors are very grateful to Dr. Anmar E. Rafik for linguistic assistance in this paper. The authors are very grateful to the Editor in Chief Prof. Dr. Salih M. Awadh, the Secretary of Journal Mr. Samir R. Hijab and the Technical Editor Dr. Heba S. Al-Mimar for their great efforts and valuable comments.

\section{REFERENCES}

Ahmad, R., Kaushik, H., and Ranjan, R. K., 2019, Assessment of microbial communities and heavy metals in urban soils of Patna, Bihar (India): Arabian Journal of Geosciences. 12 (2): 20.

Aihemaiti, A., Gao, Y., Meng, Y., Chen, X., Liu, J., Xiang, H., Xu, Y., and Jiang, J., 2019. Review of plantvanadium physiological interactions, bioaccumulation, and bioremediation of vanadium-contaminated sites: Science of The Total Environment, p. 135637. https://doi.org/10.1016/j.scitotenv.2019.135637

Akoumianaki-Ioannidou, A., Barouchas, P. E., Ilia, E., Kyramariou, A., and Moustakas, N. K., 2016. Effect of vanadium on dry matter and nutrient concentration in sweet basil ('Ocimum basilicum'L.): Australian Journal of Crop Science. 10 (2):199.

Al-Hamdani, J. A. J., Awadh, S. M., and Ibrahim, O. S., 2016. Geochemical partitioning of heavy metals in the urban soil, Kirkuk, Iraq: The Iraqi Geological Journal. 39-49 (1:) 1-24.

Al-Jaberi, M. H., Al-Dabbas, M. A., and Al-Khafaji, R., 2016. Assessment of heavy metals contamination and sediment quality in shatt al-arab river, s iraq: Iraqi Geological Journal. 39-49 (1): 88-97. 
Al-Jaberi, M. H., and A-Jafar, M. K., 2020. Elements distribution for the upper sandstone member of the Zubair formation in Zubair oil field, southern Iraq: Iraqi Geological Journal. 53(1E): 55-74.

AL-Jumaily, H. A., 2009. Geochemical evaluation of heavy metals pollution of industrial quarter soils at Kirkuk city. Northern Iraq: Kirkuk University Journal for Scientific Studies. 4 (1): 1-11.

Alekseenko, V., and Alekseenko, A., 2014. The abundances of chemical elements in urban soils: Journal of Geochemical Exploration.147: 245-249. https://doi.org/10.1016/j.gexplo.2014.08.003

Ali, H. A., 2007. Heavy metals concentrations in surface soils of the Haweja area south western of Kirkuk, Iraq: Kirkuk University Journal for Scientific Studies. 2 (3): 35-48.

Alloway, B., 1995. Heavy metals in soils, Blackie Academic \& Professional, London, 'Appendix 2'.

Alloway, B. J., 2012. Heavy metals in soils: trace metals and metalloids in soils and their bioavailability, Springer Science \& Business Media.

Awadh, S. M., 2015. Cd, Ni, and Pb distribution and pollution assessment in roadside dust from Baghdad City and Western Iraqi Desert: Arabian Journal of Geosciences. 8 (1): 315-323.

Awadh, S. M., and Al-Ankaz, Z. S., 2016. Inorganic geochemistry and origin of bitumen intruded in Euphrates and Fatha Formations in Hit area, western Iraq: Iraqi Journal of Science. 57 (4A): 2478-2489.

Awadh, S. M., and Al-hamdani, J. A. J. M. Z., 2019. Urban geochemistry assessment using pollution indices: a case study of urban soil in Kirkuk, Iraq: Environmental Earth Sciences. 78 (20): 587.

Awadh, S. M., Al-Kilabi, J. A., and Khaleefah, N. H., 2015, Comparison the geochemical background, threshold and anomaly with pollution indices in the assessment of soil pollution: Al-Hawija, north of Iraq case study: International Journal Science Resource (IJSR). 4 (7): 2357-2363.

Baken, S., Larsson, M. A., Gustafsson, J. P., Cubadda, F., and Smolders, E., 2012. Ageing of vanadium in soils and consequences for bioavailability: European Journal of Soil Science. 63 (6): 839-847.

Barceloux, D. G., and Barceloux, D., 1999. Vanadium: Journal of Toxicology 37 (2): 265-278.

Bern, C. R., Walton-Day, K., and Naftz, D. L., 2019. Improved enrichment factor calculations through principal component analysis: Examples from soils near breccia pipe uranium mines, Arizona, USA: Environmental Pollution, 248: 90-100. https://doi.org/10.1016/j.envpol.2019.01.122Get rights and content

Bolan, N. S., Khan, M., Tillman, R., Naidu, R., and Syers, J., 1999. The effects of anion sorption on sorption and leaching of cadmium: Soil Research, 37(3): 445-460.

Breit, G. N., an. d Wanty, R. B., 1991. Vanadium accumulation in carbonaceous rocks: a review of geochemical controls during deposition and diagenesis. Chemical Geology. 91(2):83-97.

Buat-Menard, P., and Chesselet, R., 1979. Variable influence of the atmospheric flux on the trace metal chemistry of oceanic suspended matter: Earth and Planetary Science Letters. 42 (3): 399-411.

Carver, R., 1971. Procedures in Sedimentary Petrology. John Willey \& Sons: Inc. Nueva York, v. 653.

Folk, R., 1980. Petrology 01'Sedimentary Rock», Austin: Hemphill. 182p.

Gäbler, H. E., Glüh, K., Bahr, A., and Utermann, J., 2009. Quantification of vanadium adsorption by German soils: Journal of Geochemical Exploration, 103 (1): 37-44.

Gan, C., Liu, M., Lu, J., and Yang, J., 2020. Adsorption and desorption characteristics of vanadium (V) on silica: water, Air, and Soil Pollution, 231(1):10.

Ghani, S. A., Shobier, A. H., and Shreadah, M. A., 2012. Assessment of arsenic and vanadium pollution in surface sediments of the Egyptian Mediterranean coast: International Journal of Environmental Technology And Management. 16 (1-2): 82-101. https://doi.org/10.1504/IJETM.2013.050673

Gransee, A., and Führs, H., 2013. Magnesium mobility in soils as a challenge for soil and plant analysis, magnesium fertilization and root uptake under adverse growth conditions: Plant and Soil. 368 (1-2): 5-21.

Gustafsson, J. P., 2019. Vanadium geochemistry in the biogeosphere, speciation, solid-solution interactions, and ecotoxicity: Applied Geochemistry, 102: 1-25.

Hakanson, L., 1980. An ecological risk index for aquatic pollution control. A sedimentological Approach: Water Research. 14 (8): 975-1001.

Hope, B. K., 1997. An assessment of global impact of anthropogenic vanadium: Biogeochemistry. 37 (1): 1-13.

Hu, X., Yue, Y., and Peng, X., 2018. Release kinetics of vanadium from vanadium (III, IV and V) oxides: Effect of $\mathrm{pH}$, temperature and oxide dose: Journal Environmetal Science (China). 67:96-103.

Huang, X., and Yang, G., 2020. Charge reversal and anion effects during adsorption of metal ions at clay surfaces: Mechanistic aspects and influence factors: Chemical Physics. 529:110575. 
Hussian, M. L., and Al-Jaberi, M. H. 2020. Comparison the bed sediment contamination of the southern part of Euphrates River with Shatt Al-arab, iraq: The Iraqi Geological Journal. v. 53, no. (1C): 68-89.

IARC, 2006. IARC monographs on the evaluation of carcinogenic risks to humans, World Health Organization.

Imtiaz, M., Rizwan, M. S., Xiong, S., Li, H., Ashraf, M., Shahzad, S. M., Shahzad, M., Rizwan, M., and Tu, S., 2015. Vanadium, recent advancements and research prospects. Environment International. 80: 79-88.

Ivanov, G. M., and Kashin, V. K., 2010. Vanadium in the landscapes of western Transbaikalia: Geochemistry International, 48 (3): 295-299.

Jaiswal, M. R., and Kale, P. P., 2019. Mini review vanadium induced neurotoxicity and possible targets: Neurological Sciences. 1-6.

Jassim, S., and Goff, J., 2006. Phanerozoic development of the northern Arabian Plate: Geology of Iraq. Dolin, Prague and Moravian Museum, Brno, 32-44.

Jayawardana, D. T., Pitawala, H. M. T. G. A., and Ishiga, H., 2014. Geochemical evidence for the accumulation of vanadium in soils of chronic kidney disease areas in Sri Lanka: Environmental Earth Sciences. 73 (9): 5415-5424.

Jiang, Y., Yin, X., Luo, X., Yu, L., Sun, H., Wang, N., and Mathews, S., 2019. Sorption of vanadium (V) on three typical agricultural soil of the Loess Plateau, China: Environmental Pollutants and Bioavailability. 31 (1): 120-130.

Johansson, C., Norman, M., and Burman, L., 2009. Road traffic emission factors for heavy metals: Atmospheric Environment. 43 (31): 4681-4688. https://doi.org/10.1016/j.atmosenv.2008.10.024

Kabata-Pendias, A., 2010, Trace elements in soils and plants, CRC press.

Kabata-Pendias, A., and Mukherjee, A. B., 2007.Trace elements from soil to human, Springer Science \& Business Media.

Kabata-Pendias, A., and Pendias, H., 1985, Trace elements in solid and plants, CRC Press.

Kaplan, D., Sajwan, K., Adriano, D., and Gettier, S., 1990. Phytoavailability and toxicity of beryllium and vanadium: Water, air, and soil pollution. 53 (3-4): 203-212.

Karak, T., Das, D. K., Singh, U. K., and Maiti, D., 2005. Influence of pH on soil charge characteristics and cadmium sorption in some noncontaminated soils of Indian subtropics. Scientific World Journal. 5:183-194.

Khan, A., Khan, S., Khan, M. A., Qamar, Z., and Waqas, M., 2015. The uptake and bioaccumulation of heavy metals by food plants, their effects on plants nutrients, and associated health risk: a review: Environmental Science and Pollution Research. 22 (18):13772-13799.

Linhares, D., Pimentel, A., Borges, C., Cruz, J. V., Garcia, P., and dos Santos Rodrigues, A., 2019. Cobalt distribution in the soils of São Miguel Island (Azores): From volcanoes to health effects: Science of The Total Environment. 684: 715-721. https://doi.org/10.1016/j.scitotenv.2019.05.359

Liu, C., Eleish, A., Hystad, G., Golden, J. J., Downs, R. T., Morrison, S. M., Hummer, D. R., Ralph, J. P., Fox, P., and Hazen, R. M., 2018. Analysis and visualization of vanadium mineral diversity and distribution: American Mineralogist. 103 (7):1080-1086.

Mandiwana, K. L., and Panichev, N., 2004. Electrothermal atomic absorption spectrometric determination of vanadium (V) in soil after leaching with Na2CO3: Analytica Chimica Acta. 517 (1-2): 201-206.

Mayland, H., and Wilkinson, S., 1989. Soil factors affecting magnesium availability in plant-animal systems: a review: Journal of Animal Science. 67 (12): 3437-3444. https://doi.org/10.2527/jas1989.67123437x

Mejia, J. A., Rodriguez, R., Armienta, A., Mata, E., and Fiorucci, A., 2007, Aquifer Vulnerability Zoning, an Indicator of Atmospheric Pollutants Input? Vanadium in the Salamanca Aquifer, Mexico: Water, Air, and Soil Pollution. 185 (1-4): 95-100.

Micó, C., Recatalá, L., Peris, M., and Sánchez, J., 2006. Assessing heavy metal sources in agricultural soils of an European Mediterranean area by multivariate analysis: Chemosphere. 65 (5): 863-872.

Mohammed, F. A., 2009. Pollution caused by vehicle exhausts and oil trash burning in Kirkuk city: Iraqi National Journal of Earth Science. 9 (2): 39-48.

Muhammad, Z. A., and Ali, I. M., 2018, Use multiple analysis methods to study the most important influencing factors Between the sexes and diabetes: Qalaai Zanist Journal. 3 (4). https://doi.org/10.25212/lfu.qzj.3.4.21

Naeem, A., Westerhoff, P., and Mustafa, S., 2007. Vanadium removal by metal (hydr)oxide adsorbents: Water Resource. 41 (7): 1596-1602. https://doi.org/10.1016/j.watres.2007.01.002

Nalewajko, C., Lee, K., and Olaveson, M., 1995. Responses of freshwater algae to inhibitory vanadium concentrations: The role of phosphorus 1: Journal of Phycology. 31 (3): 332-343. 
Naser, H., Rahman, M., Sultana, S., Quddus, M., and Hossain, M., 2018. Heavy metal accumulation in leafy vegetables grown in industrial areas under varying levels of pollution: Bangladesh Journal of Agricultural Research. 43 (1): 39-51. https://doi.org/10.3329/bjar.v43i1.36157

Nkwopara, U., Okoli, N., Osisi, A., Ihem, E., Ekpe, I., Okon, M., and Hu, H., 2016. Effect of some operating variables on adsorption of lead on variable charge soils of Southern China: Research Journal of Agriculture and Environmental Management. 5(6):177-186.

Othman, S. M., Sarsam, S. I., and Ismail, S. A., 2020. Gypsum and limestone dissolution within Fatha Formation (Middle Miocene) at various ph solutions: a laboratory study: The Iraqi Geological Journal. 53 (2B): 71-88. http://igj-iraq.org/igj/index.php/igj/article/view/184

Peng, J.-f., Song, Y.-h., Yuan, P., Cui, X.-y., and Qiu, G.-1., 2009. The remediation of heavy metals contaminated sediment: Journal of hazardous materials.161( 2-3): 633-640.

Pourret, O., and Faucon, M.-P., 2018, Cobalt.

Pragg, C., and Mohammed, F. K., 2018. Pollution status, ecological risk assessment and source identification of heavy metals in road dust from an Industrial Estate in Trinidad, West Indies: Chemistry and Ecology. 34 (7): 624-639. https://doi.org/10.1080/02757540.2018.1482887

Pyrzyñska, K., 2006. Selected problems in speciation analysis of vanadium in water samples: Chemia analityczna, 51(3): 339.

Reijonen, I., Metzler, M., and Hartikainen, H., 2016. Impact of soil pH and organic matter on the chemical bioavailability of vanadium species: the underlying basis for risk assessment: Environmental Pollution. 210: 371-379.

Ruyters, S., Mertens, J., Vassilieva, E., Dehandschutter, B., Poffijn, A., and Smolders, E., 2011. The red mud accident in ajka (hungary): plant toxicity and trace metal bioavailability in red mud contaminated soil: Environmental Science Technology. 45(4): 1616-1622.

Rzger, A. A., Mohammed, H. H., Lawko, A. I., and Chrokhan, T. M., 2018. Oil-oil correlation using trace metals from selected oil fields, North Iraq: Iraqi Bulletin of Geology and Mining.14 (2): 71-80.

Schiffer, S., and Liber, K., 2017. Toxicity of aqueous vanadium to zooplankton and phytoplankton species of relevance to the athabasca oil sands region: Ecotoxicol Environ Saf.137:1-11.

Schlesinger, W. H., Klein, E. M., and Vengosh, A., 2017. Global biogeochemical cycle of vanadium: Proc Natl Acad Sci U. S. A. 114 (52): E11092-E11100. https://doi.org/10.1073/pnas.1715500114

Shaheen, S. M., Rinklebe, J., Frohne, T., White, J. R., and DeLaune, R. D., 2014. Biogeochemical factors governing cobalt, nickel, selenium, and vanadium dynamics in periodically flooded Egyptian North Nile Delta rice soils: Soil Science Society of America Journal. 78 (3): 1065-1078.

Sherene, T., 2010. Mobility and transport of heavy metals in polluted soil environment, in Proceedings Biological forum, International Journal. 2:112-121.

Sun, W., Li, X., Padilla, J., Elbana, T. A., and Selim, H. M., 2019. The influence of phosphate on the adsorptiondesorption kinetics of vanadium in an acidic soil: Journal of Environmental Quality. 48 (3):686-693.

Teng, Y., Yang, J., Sun, Z., Wang, J., Zuo, R., and Zheng, J., 2011. Environmental vanadium distribution, mobility and bioaccumulation in different land-use districts in panzhihua region, SW China: Environmental Monitoring and Assessment. 176 (1-4): 605-620. https://doi.org/10.1007/s10661-010-1607-0

Wällstedt, T., Björkvald, L., and Gustafsson, J. P., 2010. Increasing concentrations of arsenic and vanadium in (southern) Swedish streams: Applied Geochemistry. 25 (8):1162-1175.

Watt, J. A. J., Burke, I. T., Edwards, R. A., Malcolm, H. M., Mayes, W. M., Olszewska, J. P., Pan, G., Graham, M. C., Heal, K. V., Rose, N. L., Turner, S. D., and Spears, B. M., 2018. Vanadium: a re-emerging environmental hazard: Environmental Science Technology. 52 (21):11973-11974.

Wilk, A., Szypulska-Koziarska, D., and Wiszniewska, B., 2017. The toxicity of vanadium on gastrointestinal, urinary and reproductive system, and its influence on fertility and fetuses malformations: Advances in Hygiene \& Experimental Medicine, Postepy Higieny i Medycyny Doswiadczalnej, 71.

Wisawapipat, W., and Kretzschmar, R., 2017. Solid phase speciation and solubility of vanadium in highly weathered soils: Environmental Science Technology. 51 (15): 8254-8262.

Yang, J., Tang, Y., Yang, K., Rouff, A. A., Elzinga, E. J., and Huang, J.-H., 2014. Leaching characteristics of vanadium in mine tailings and soils near a vanadium titanomagnetite mining site: Journal of hazardous materials. 264: 498-504. https://doi.org/10.1016/j.jhazmat.2013.09.063 
Yaqin, J., Yinchang, F., Jianhui, W., Tan, Z., Zhipeng, B., and Chiqing, D., 2008. Using geoaccumulation index to study source profiles of soil dust in China: Journal of Environmental Sciences. 20 (5): 571-578.

Yassin, O. A., and Al-Awadie, N. S. T., 2014. New approach for the on-line spectrophotometric determination of vanadium (v) in different river water via the use of a homemade ayah 6 sx1-t-2d solar-continuous flow injection analyser. Iraqi Journal of Science. 55 (4B):1721-1735.

Zhang, N., Li, H.-X., Cheng, H.-J., and Liu, X.-M., 2017. Electron probe microanalysis for revealing occurrence mode of scandium in Bayer red mud: Rare Metals. 36 (4): 295-303.

Zhang, W., Jiang, J., Li, K., Li, T., Li, D. a., and Wang, J., 2018. Amendment of vanadium-contaminated soil with soil conditioners: A study based on pot experiments with canola plants (Brassica campestris L.): International Journal of Phytoremediation. 20 (5): 454-461.

Zhu, H., Xiao, X., Guo, Z., Han, X., Liang, Y., Zhang, Y., and Zhou, C., 2018. Adsorption of vanadium (V) on natural kaolinite and montmorillonite: characteristics and mechanism, Applied Clay Science. 161: 310-316.

Zou, Q., Li, D., Jiang, J., Aihemaiti, A., Gao, Y., Liu, N., and Liu, J., 2019. Geochemical simulation of the stabilization process of vanadium-contaminated soil remediated with calcium oxide and ferrous sulfate: Ecotoxicol Environ Saf. 174: 498-505. https://doi.org/10.1016/j.ecoenv.2019.02.082 